\section{INTERNATIONAL IDD OVERVIEW - PECULIARITIES AND CHALLENGES IN EU COUNTRIES}

Orbán Barbara és Urbán Dóra (a Deloitte Zrt. Aktuáriusi és Biztositási Megoldások csapatának szenior tanácsadó aktuáriusai),borban@deloittece.com,durban@deloittece.com

\section{ÖSSZEFOGLALÓ}

A Deloitte közép-európai csapata 2018 végén európai uniós szintű IDD (Insurance Distribution Directive) felmérést végzett, amelyben a magyar iroda Aktuáriusi és Biztosítási Megoldások csapata is közremüködött. Nemzetközi hálózatunk segítségével információkat gyüjtöttünk az IDD nemzeti jogszabályokba való átültetésének állapotáról, kihívásairól és a várható hatásokról a kutatásban részt vevő országok esetében. A felmérés egy kérdőív kitöltésével és értékelésével valósult meg. Cikkünkben szeretnénk röviden bemutatni a biztositási termékek elöállítóira és a közvetítőkre vonatkozó új szabályozás legfontosabb követelményeit. A felmérés eredményei alapján rávilágítunk a jogszabályi átültetés és az implementáció nehézségeire a tagországok esetében, illetve ismertetjük saját tapasztalataink alapján a magyar biztosítási piac számára legnagyobb kihívást jelentő követelményeket és a szabályozás magyar specifikumait.

\section{SUMMARY}

The Central European Deloitte team performed an internal EU IDD study at the end of 2018 in which the Hungarian Actuarial and Insurance Solutions team also participated. Through our international network, we collected information on the IDD transposition status, challenges and impacts on the insurance sector perceived in the participating countries. The information was gathered through the completion of a survey. In our article we would like to introduce the main requirements of the new regulation on manufacturers and intermediaries of insurance products in a nutshell. We highlight the key transpositional and implementation difficulties based on the survey results and give our understanding of the most important implementation issues in the Hungarian insurance market and the local peculiarities.

Kulcsszavak: IDD, POG, alkalmasság és megfelelés, javadalmazás, összeférhetetlenség Key words: IDD, POG, suitability and appropriateness, inducements, conflicts of interest

JEL: G22, G28, H73, K33

DOI: $10.18530 /$ BK.2019.2.38

http://dx.doi.org/10.18530/BK.2019.2.38

\section{Transposition and implementation status}

At the issue date of the survey ${ }^{1}$ results, the final transposition text of IDD had been published in most of the EU Member States. The aim of the new EU regulation is to improve the customer protection, via introducing minimum harmonisation requirements across the EU regarding product development, maintenance and distribution. The ultimate goal is to provide the product to all the customers that fits the best to their needs and possibilities at the end of the sales process. Nevertheless, in spite of the deadline of 1 July 2018 to transpose the Directive ${ }^{2}$ and of 1 October 2018 to implement it, at the end of 2018 some countries were still waiting for the final version to be adopted and published. The original deadline of the implementation had been delayed from 23 February 2018, however some countries (e.g Germany, Hungary, Slovakia) transposed the original effective date to their local regulations. The same went for the efforts ongoing within the insurance industry to implement the diverse set of IDD requirements. Some countries and firms were already in the post-implementation phase at the end of 2018, while others were still in the process of moving ahead and putting in place large implementation programs in order to identify gaps against the existing regulation. In this manner they can determine the impact on their businesses and the related actions to take. At the same time, in other countries the insurance sector has just started to analyse the tasks and define the initial actions.

The focus on meeting multiple regulatory deadlines in 2018 came with a significant opportunity cost. Firms had been struggling with various and competing regulatory priorities: their regulatory change agendas were in 2018 mostly ranked by Anti-Money Laundering, GDPR, followed by IFRS 17 on the prudential side. PRIIPs ${ }^{3}$ and IDD appeared to be on lower levels on firms' priority list. Due to all these challenges, insurance companies will likely have to undertake significant remediation work in the upcoming years, to make the compliance efficient and appropriate after the effective date of IDD.

\section{Product Oversight and Governance}

\section{IDD requirements}

Product oversight and governance (hereinafter referred to as POG) is one of the topics those are seen as the most challenging in terms of implementation of IDD requirements due to its novelty.

The Directive states that manufacturers shall operate a process for the approval of any insurance product for sale before they are distributed to customers. During this process manufacturers should specify identified target market for each product, taking into account all the possible risks, and they should take reasonable steps to ensure that the product is distributed to its target market. 
After launching products to the market, insurance companies shall regularly review them, identify any factor that could materially affect the risk of the distribution, and they shall assess whether the product remains appropriate to the needs of the target group. Specific rules for manufacturers and for distributors are elaborated in the level 2 regulation ${ }^{4}$.

These new rules introduced by IDD will require firms to align their product strategy with their target market through an ongoing product development and review process that centers around customers' demands and needs and it proactively manages customer risks and conflicts of interest. This will have an impact on the end-to-end product value chain, including all the the distribution channels.

Transposition in local laws, key challenges in EU

As the POG rules are mostly new to the majority of the EU Member States in terms of national legislation, all the national regulators, except for Hungary and the UK, opted for a literal transposition of the Directive.

All the national regulators, except for Hungary and the UK, opted for a literal transposition of the Directive.

In France, manufacturers already had requirements in place for product approval and launching process before the effective date of IDD. However, those requirements were mainly focused on the technical aspects of the product development, such as pricing and profitability conditions, instead of customer protection initiatives. The main challenge of IDD transposition for France was to complete the regulation of those processes with sufficient risk assessment steps, such as conflicts of interests risk evaluation. In addition, the product oversight requirements of the Directive required them to strengthen their controls over the distribution channels, especially for brokers, where there were no strict rules of supervision previously. According to insurance companies operating in France, the POG will be a key area of focus of the French Prudential Supervision and Resolution Authority (ACPR) in the next years.

The POG requirements are also challenging part of the implementation process in Italy. Insurance companies declared that it forces them to evaluate critically their product offering and the characteristics of products offered to the customers. The development of POG procedures and policies has had a bigger impact on non-life firms in Ireland. Reporting and MI (market intelligence) had been addressed previously under different local regulations but are now required to be built into the POG processes. The impact is significant for intermediaries as they were only partly affected by the previous regime.

In the Netherlands, the overall business impact of IDD is seen as quite low, because many requirements are close to the existing regime. One of the main challenges is of course related to the POG requirements, as it seems to be a brand new topic to them as well.

Regarding the UK, the local regulator has gold-plated conduct regulation under $\mathrm{IMD}^{5}$.
Therefore, implementation of IDD in the UK is likely to be relatively less problematic. As the MiFID II requirements regarding product governance go further than IDD on some specific areas of product governance, the British regulator has aligned its local legislation to those of MiFID II. This includes requirements to provide distributors with additional information about the target market assessment and the need to assess the cost structure of products as part of POG processes. In addition, the Financial Conduct Authority previously had a guidance in form of a handbook that covered the same topics as IDD discusses. The regulator plans to reform it into a new guidance book on product oversight and governance. It has to be highlighted at this point that the core conduct requirements of IDD are under the remit of the host country's supervisor, therefore insurers and intermediaries foreseeing to restructure their business due to Brexit should plan and implement their processes in line with the relevant jurisdictions.

\section{Hungary}

As there were no POG-like requirements in Hungary before IDD, the new regulation causes significantly more administration issues to companies. The product monitoring and review requirements of the Hungarian Insurance Act are stricter than IDD in the sense that rules have to be applied also for products being sold on 23 February 2018 - which means that they were launched before or at that date -, while IDD doesn't specify retrospective application of POG requirements. For these products, the target market, its needs and the appropriate sales strategy had to be identified by 23 February 2019, and periodic assessment of them has to be performed annually. This extension of the Directive might require significant amount of administration and assessment work from companies. However, there are some subsidiaries of international insurance groups in Hungary, where product approval and review processes were required by the parent company even before IDD. For them the application of POG rules will only mean minor amendments in their current processes and administration.

\section{Giving advice and customer tests}

\section{IDD requirements}

In line with MiFID II, IDD initiates a number of changes to the sales process. It introduces the concept of sales with and without providing advice. Sales with advice means that a personalized recommendation is to be provided, explaining the link between the product and the customer's needs and characteristics. In order to do this, the sufficient information has to be collected through customer tests. When advice is given, the suitability assessment has to be perfomed in case of IBIPs (insurance-based investment products). This means that an in-depth 'know your customer' process needs to be put in place to obtain information on the knowledge and experience in the investment field, financial situation, ability to bear losses and investment objectives of the customer. In case of IBIP sales without advice the assessment of appropriateness has to be 
performed aiming to ensure that the insurance service or product envisaged is appropriate for the customer: the potential customer's financial knowledge and experience regarding the relevant investment field have to be analysed. A general demands and needs test has to be fulfilled and assessed in both cases, for all types of products.

When advice is given in relation to an IBIP, it should be recorded during the sales process whether the insurance distributor will provide the customer with a periodic assessment of the suitability of the product concluded. Member States may permit firms to carry out insurance distribution activities without performing the suitability and appropriateness test (known as the 'execution-only regime') under certain conditions ${ }^{6}$ with regard to so-called non-complex products. ${ }^{7}$

Firms offering automated digital sales and advice, and websites providing aggregators/price comparison will also have to ensure that customer journeys, including underlying algorithms, adhere to these different requirements.

\section{Transposition in local laws, key challenges in EU}

When transposing IDD, Member States had the opportunity to impose stricter rules regarding giving advice during the sales process, therefore the requirements vary state by state. In Germany, Belgium, Ireland, and the Netherlands the provision of advice is not mandatory, while in Spain and in Poland, it is mandatory only when the product is sold through a broker. The legislation of Denmark, Greece and Czech Republic require intermediaries to provide advice for all the insurance products and sales channels. Italy, Hungary, the UK and France chose the option of oblige the intermediaries and insurance undertakings to provide advice for IBIPs only.

Besides Poland and the Netherlands, all countries chose not to employ the execution-only regime option.

In Belgium, the legislator decided to maintain as much as possible from the existing regime, but additionally imposed slightly stricter rules with regard to the definition of independent advice in relation to IBIPs (inspired by MiFID II). This means that customers might ask for a broader assessment from the intermediary, and in these cases the intermediary shall assess sufficiently large number of insurance products available on the market and shall not be limited to insurance products provided by companies having close links with the intermediary.

Besides Poland and the Netherlands, all countries chose not to employ the executiononly regime option. In Poland, the execution-only regime only applies when the insurance distribution is performed by a broker. In that case, the customer can sign a statement where they state that they resign from getting advice at point of sale and the related customer protection benefits.

The general demands and needs analysis rules were literally transposed by most of the Member States. The suitability and appropriateness requirements for IBIPs were literally transposed by Spain, Italy, Germany, Czech Republic, Denmark, the Netherlands, France, Greece and the UK. In Poland, these requirements are applicable only in the relation between an insurance undertaking and the policyholder. Polish rules in this respect do not consider insurance intermediaries.

While the general demands and needs analysis and the assessment of suitability and appropriateness for IBIPs have already existed in France, the ACPR (local regulator) plans to take the IDD opportunity to (re)check that distributors have put in place appropriate measures to ensure the products distributed are consistent with customers profile and requests. Also in Ireland, there were a Consumer Protection Codex already in place before IDD for life insurance products with investment purpose. In the UK, insurance companies operating in the non-life business had to amend their fact-finding processes in order to be more proactive in seeking meaningful information on the customer's demands and needs. On the other hand, Deloitte experts found that it didn't have a high impact on the operation as these assessments had already existed in the life business and they could leverage from them. Regarding the Czech Republic, the implementation of customer tests had a high impact on the business processes in terms of preparation of appropriate softwares to capture all the demands, needs and based on those be able to provide advice.

In the survey, participants were asked whether the IBIPs rules - meaning the assessment of suitability and appropriateness - were also going to be applicable to non-life products. Beside Denmark, no country decided to impose such stricter rules to non-life products.

\section{Hungary}

One of the specialities of the Hungarian transposition is that giving advice is compulsory for IBIPs, therefore sensitive information such as the source and extent of amount of the potential customers' regular income and savings have to be collected. This makes the sales process a bit more complicated for insurance distributors, as willingness to share financial status is not general by potential customers, Hungarian people handle it as a very sensitive topic.

The option of the regular assessment of suitability for IBIPs is mentioned in the Hungarian Insurance Act, but it is not compulsory. However, the experience from the regular MiFID II assessment of the banking practice might have been utilized, the Hungarian market foresees this task as very challenging, because multi-channel solutions might have been elaborated, that causes IT and sales complexities.

In Hungary, the synergy between the local regulation (before IDD) and the new EU rules could be utilised regarding the customer testing requirements as the Hungarian National Bank issued a regulation on compulsory customer needs assessment form for life insurance products in 2015 - that has been repealed by them in 2018. Those questions have significant overlap with the general demands and needs test of IDD, but contain some additional questions, therefore topics to be discussed with the customer during a sales 
process in Hungary is wider than in IDD. Based on the assessment of publicly available customer questionnaire forms it can be stated that most of the companies merged the general demands and need test - with the abovementioned extra questions required by local regulator - and the suitability/appropriateness questions. Some of the companies have automated their questionnaires for assessing the answer set in a more efficient way than it can be perfomed on a paper-based form. This development process has caused some IT complexities, on the other hand, it has significantly affected the sales process.

\section{Transparency}

IDD requirements

Alongside PRIIPs regulation, IDD imposes increased disclosure on costs and charges for insurance-based investment products. Distributors shall also provide the customer with the relevant information about the insurance product in a comprehensible form. IDD introduces the Product Information Document (PID or IPID - Insurance Product Information Document), a standardized document summarizing the main features of a non-life insurance contract. ${ }^{8}$ If the insurance product is sold together with an ancillary non-insurance product or service in a package, information on the components and their costs and charges have to be provided to the customer, if they are available on the market separately. Where the insurance product is the ancillary one in the package, the insurance distributor shall offer the customer the possibility of buying the good or service separately (exceptions are listed in Article 24 of the Directive).

When advice is given during the sales of an IBIP, a suitability statement has to be provided to the customer that presents how the offered product or product package and its attributes meet the preferences, objectives and other characteristics of the customer. In case advice is given during the sales of a non-life product, this information also has to be provided to the client, although its form is not strictly defined in the regulation.

IDD imposes a new transparency rule regarding the nature of the remuneration, which has to be provided to the customer at point of sale in case of every product type, in addition in case of insurance intermediaries, the source of the remuneration also has to be disclosed.

\section{Transposition in local laws, key challenges in EU}

Except for Belgium and Italy, all countries opted for a literal transposition of the transparency and reporting rules. In Italy, the regime is stricter than the IDD requirements as the IPID shall be provided also for non-IBIP life products ('Documento Informativo Pre-contrattuale Vita'). On top of that the 'DIP Aggiuntivo', an additional document that has to be provided for all product categories, was introduced by the Italian Insurance Code.
It contains information on the issuer, as well as further information regarding rights and obligations of the contracting parties.

In Belgium, the main impacts of IDD are expected to be within the information to customer requirements (the IPID) besides POG rules, as these are completely new. The transposed transparency requirements are stricter than the minimum requirements of IDD, in terms of presentation of costs and charges regarding both life and non-life products.

\section{Many of the participating countries fear that IDD will lead to} an overload of customer information documents.

Most of the countries involved in the survey reported that the increased disclosure on cross-selling will have business implications as firms will need to price and offer components separately for certain tied products.

Many of the participating countries fear that IDD will lead to an overload of customer information documents. The Netherlands, the UK, Germany and Hungary are the countries expecting the least impact of transparency requirements on the Insurance Sector. Based on our survey, Spain, Greece and Poland are the most impacted countries by IDD transparency rules based on the requirements of the previously effective local regulation.

\section{Hungary}

In Hungary, there were multiple transparency requirements already in force before IDD, therefore regarding the life insurance business, the new regulation only mean minor amendments to the previously existing processes and documentation. The cost and charges of unit-linked products had to be disclosed as part of the terms and conditions required by the Recommendation of Hungarian National Bank on unit-linked products. In addition, the TKM ratios ${ }^{10}$ of saving products have to be provided to customers before point of sale - it is compulsory for the whole market since $2016^{11}$. For life products, a so-called 'Life insurance product information document' already had been required by the Hungarian Insurance Act before IDD came into force. Amongst other information about the product, it should be presented on this document how the offered product and its main attributes meet the customer's insurance objectives. As it already has significant overlap with the suitability statement required by IDD, the Hungarian market could take advantage of it and finally some of the insurance companies have merged the two statements.

For the non-life insurance products, the relevant processes and customer information material had to be elaborated to be in line with IDD requirements.

Based on our experience, product unbundling requirements are also challenging to the local market, as information on products offered via cross-selling has to be provided as if they were sold as stand-alone products, therefore additional customer information materials have to be created. 


\section{Professional requirements}

\section{IDD requirements}

The Directive sets professional requirements for insurance intermediaries, employees of insurance undertakings and employees of insurance intermediaries in order to enhance and support the ongoing knowledge and capability of staff, in particular of those who sell the product to customers. In practice, this means the completion of at least 15 hours of professional or development training per year (courses, e-learning, mentoring etc.) aligned with the nature of the products sold and the role of or the activity carried out by the person following the training. Besides, if subsequent change in the firm's products and processes happen, they are expected to be incorporated into the training package as well. This also means that these new professional requirements will require firms to review their training, development and performance management processes. Member states may require obtaining a certificate that proves the successful completion of the training.

Transposition in local laws, key challenges in EU

The Spanish regulator's intention is to gold-plate the rules applicable under IDD by setting up an increased level of knowledge and ongoing professional trainings (on a 3-level basis), which could lead to a redesign of the distribution chain due to the training and qualifications needed to provide advice. This intention involves the imposition of these professional requirements to all employees, except the ancillary roles, with a possible higher number of mandatory hours per year, depending on the level of involvement in the insurance distribution. Further guidance from the regulator is expected in the coming months. In France, the biggest effort is expected from the distributors who have to set up new reporting framework with processes and IT impacts in order to be able to track more accurately the completion of their salesforces continuous training hours.

While in all countries these trainings are compulsory for all the employees of insurance and reinsurance intermediaries who are involved in the insurance distribution and noncompulsory for people fulfilling ancillary roles, the transposition differs when it comes to claims handlers and call centers. France, Germany, Hungary, Belgium, Greece and the Netherlands decided not to impose the professional requirements to claims handlers, while the position in Italy, Czech Republic and Poland remains unclear at the moment.

In the Czech Republic the system of exams for distributors and their employees becomes more time demanding with IDD. A substantial impact on IBIPs and the current advisory models is expected. More requirements (reporting, registration, etc.) and stricter regulation are expected to cause a decrease in the number of distributors in the market.

When it comes to call centers, most of the countries seem to take the position that the employees will have to comply with the professional requirements if they are functioning as a sales channel, except for the Netherlands. Position in Germany, Belgium and Poland remains currently blurred.

Hungary

The 15 hours of compulsory professional trainings for the calendar year of 2018 had to be fulfilled by 23 February 2019 in line with the Hungarian Insurance Act. In addition, the trainings have to be accomplished via at least two different types of training methods (e.g. in-person, e-learning, mentoring or with attendance at professional conference). The training hour and method requirements are not applicable to people practising insurance distribution as an ancillary activity.

Based on our information from the Hungarian market, companies who sell insurance via bank branches (and therefore have a vast number of distributors) found problematic to fulfil the 15-hour compulsory training requirement, because of the availability of distributor colleagues.

\section{Conflicts of interest}

\section{IDD requirements}

In the additional requirements for IBIPs, IDD foresees conflicts of interest specific rules that impose insurance distributors to maintain effective arrangements and take steps to identify, prevent and manage conflicts of interest adversely affecting the customers' interests. The existence or possibility of conflicts of interest also has to be identyfied throughout every layer directly or indirectly affected by the sales process: between the insurance companies and the intermediaries, management and employees, intermediaries and customers and also between one customer and another. If it is not possible to ensure with appropriate prevention actions that the conflicts of interest will not have a detrimental impact on the customer, this fact should be clearly disclosed to them before the conclusion of the insurance contract. For example, the customer always has to be informed about the nature of the remuneration paid to the distributor.

Transposition in local laws, key challenges in EU

Most of the Member States literally transposed the requirements with regard to conflicts of interests applicable to IBIPs under IDD. Belgium, Denmark and the UK however decided to impose these rules to all insurance products. Before IDD application in the UK under Financial Conduct of Authority's rules, intermediaries had to present the source and extent of commission on demand to commercial customers only, therefore this IDD requirement does not have a significant effect on the related processes currently in place. 
In France, these requirements will have mid-term impacts on the IBIPs distribution value chain and might require life insurers and distributors to increase transparency to the customers on ex-post costs and charges on policy level in line with MiFID II. Open discussion about this topic is currently ongoing on the French insurance market.

The Irish market found the proper determination of disclosures challenging in terms of conflicts of interest that serves as a last resort if the conflicts cannot be avoided.

\section{Hungary}

The Hungarian Insurance Act literally transposed the conflicts of interest requirements of IDD. To our understanding, it seems to be challenging to the market players to provide the required information on the remuneration to the customers.

\section{To have clear remuneration rules and structures that consider the} best interests of their customers.

The general practice in Hungary is that the commission is included in the tariff of the product and not separately paid to the intermediary by the customer, therefore customers did not get clear information on the nature of the remuneration until the effective date of IDD. In addition, the selection of the asset managers and their relation to the insurance companies also have to be investigated, which is challenging as well.

\section{Inducements}

\section{IDD requirements}

IDD reinforces a more customer-centric approach by requiring firms to have clear remuneration rules and structures that consider the best interests of their customers. For insurance-based investment products, inducements are only acceptable if they do not have a detrimental impact on the quality of the service provided to the customer, except for cases when it is paid by the customer or the person acting on behalf of the customer.

Detrimental impact might occur in those cases where the incentive given to the distributor might indicate that the insurance distribution activity is carried out in way that is not in line with the best interest of the customer. For the identification of these cases, insurance companies shall regularly overview their relevant procedures and policies on incentives.

\section{Transposition in local laws, key challenges in EU}

These new requirements will lead firms in most of the jurisdictions to rethink their incentive and distribution strategies and as a result, it will increase market competition in terms of pricing and margin pressures. Member States may limit or prohibit the acceptance of inducements in relation to distribution or the provision of advice. However, most of the countries transposed the inducements requirements literally, without any gold-plating, in Spain, the Netherlands and Poland, the national regime regarding IBIPs has been made stricter that what IDD foresees. Ireland is the only country where the stricter IBIPs rules have been made applicable to non-life products.

In Spain, brokers are only allowed to accept fees directly from the customers. Due to the changes in the regulation of inducements and IBIP sales process, a shift between broker and agent channel is expected in the Spanish market. With the transposition of IDD, the Dutch regulator introduced the commission ban for complex financial (investment-based) products including life insurance, income insurance and funeral products. In Poland, the Financial Conduct Authority's general approach has been levelling this area up to the stricter MiFID II standards.

The inducements requirements are completely new under French law and changes in the insurance companies' business strategy are expected due to the restriction of certain types of commission schemes that may lead to customer detriment and misconduct issues. A peculiarity of the Czech market is that the local regulator requires firms to apply a compulsory five-year commission clawback system for all the regular premium life insurance products as part of their customer protection actions.

In Belgium, what occupied the insurance sector the most last year were the inducements requirements. With the transposition of IDD, the previous local 'enhancement regime' (in line with MiFID II) has been abolished and replaced by the 'no detrimental impact' regime (to align with IDD) and also the scope of application has been reduced to IBIPs - previously the inducement regime was applicable to all types of insurance products. In addition, the insurance sector is currently working on the draft of an inducement code, as it is required by the local regulator.

Based on Deloitte's survey results, the redesign of remuneration schemes is most likely to happen in Spain, Hungary and Poland. France, Greece, Italy, Belgium, Czech Republic, Denmark and Ireland rated this possible impact of IDD as medium level.

Hungary

The Hungarian Insurance Act has literally transposed the inducement requirements of the EU regulation, with the specification of the rules to independent and tied agents and intermediaries fulfilling ancillary roles. Regulation on inducements is not totally new to the local insurance market, as Insurance Act determines a cap for the payable commission amount in the first policy year in case of regular premium saving life products. It is decreased to the sum of 12 monthly premium written from 2019, but it was already regulated in the previous years, and it also remains effective in parallel with the application of IDD. For all the saving life products, the sum of commission paid shall not exceed the amount of the sum of premiums received until the date of commission payment. While 
in case of regular premium savings products, this is valid for the premium received and commission paid during the whole term of the policy. As the EU regulation introduces the qualitative requirements on top of these quantitative pecularities, the redesign of the distribution chains and remuneration schemes is expected in the local market as well. One of the biggest challenges for insurers is to reconsider the idea of sales competitions - which is a frequent practice here - to avoid any possible detrimental effect.

\section{Supervisory control}

A majority of the participating countries answered that the intention of the national regulator in terms of tracking IDD compliance is not clear yet. It is publicly announced that the French and Spanish regulators will leave the sector sufficient time to implement IDD, while the Belgian regulator initiated to conduct inspections within the sector as of January 2019. Therefore, in Belgium, most of the internal auditors were scheduling dedicated IDD compliance audit in their audit plan for year 2019. In Greece, the regulator announced that the inspections will start in the 2nd quarter of 2019.

In Hungary, Italy, Denmark and Ireland, it is not clear yet whether an external auditor will be required to include an IDD audit in its annual control program or to express an opinion on IDD compliance. In Germany, the position of the legislator is still not clear but it should be noted that even if under German-GAAP (HGB) there is no explicit report requested, the external auditor - within the scope of its mandate - can always decide to focus on the compliance with the new legal requirements.

1. Table: Key implementation challenges per topics

$$
\begin{aligned}
& { }_{\mathrm{FR}} \quad \frac{\overline{\mathrm{s}}}{\mathrm{SPR}} \\
& 1{ }_{\mathrm{DE}}=
\end{aligned}
$$

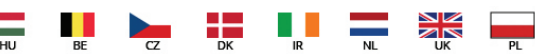

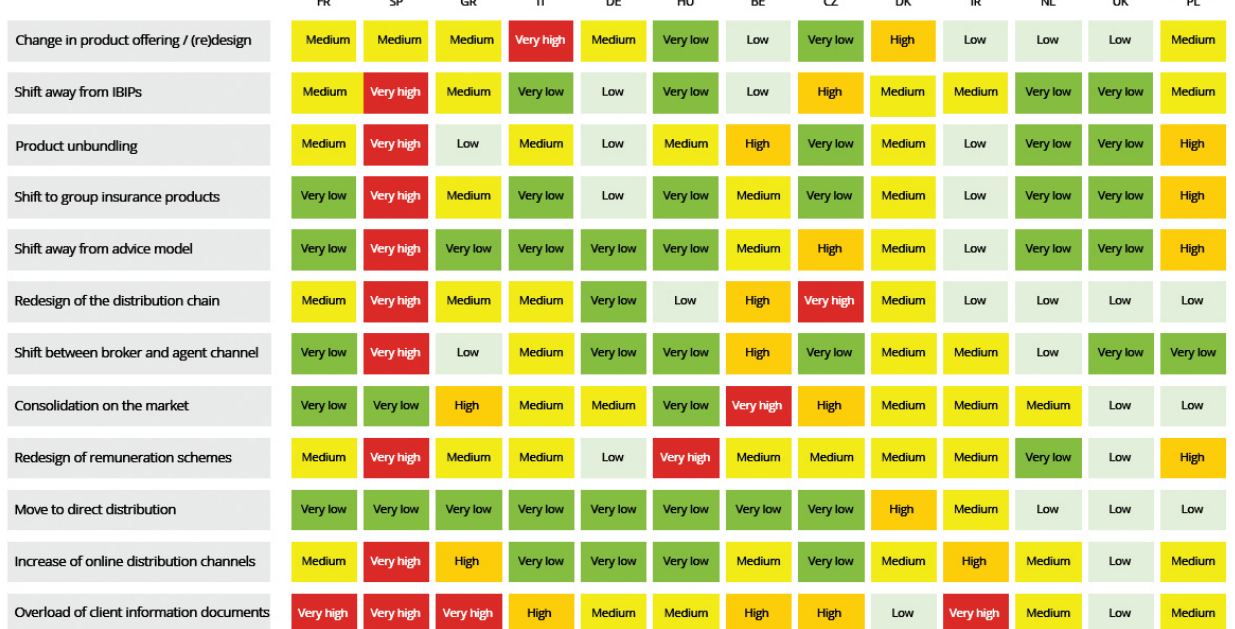

Source: Deloitte EU IDD survey, January 2019.

\section{Impacts on the insurance secto}

The overall impact of IDD on the insurance sector is unpredictable at the moment, as we are just some months after the effective date. Regarding a possible change in the product offering, most of the participants rated the expected impact as low or medium, except for Italy and Denmark who respectively see this effect as very high. In addition, the shift away from IBIPs has a high probability in Spain and the Czech Republic. Product unbundling and shift to group insurance products, mostly due to cross-selling requirements consequences of IDD are expected in Poland, Spain and Belgium. The amendments of remuneration structures and inducements frameworks will have a fundamental impact on the European insurance and distribution landscape, the Spanish market sees a high risk of a shift between the broker and agent channel. The requirements of the needs analysis, the suitability and appropriateness regime and customer information are expected to have the greatest impact on insurance companies' target operating models. Overall, it appears that the new regulation could very likely lead to a consolidation in the market, resulting in the decrease in the number of distributors, especially in Greece, Belgium and the Czech Republic. (See Table No.1.)

\section{HIVATKOZÁSOK}

'The following countries were consulted with: Belgium, the Netherlands, France, Germany, Italy, Spain, the Czech Republic, Poland, Greece, Hungary. Ireland and the United Kingdom. We must note that customers' information is not presented explicitly in the survey.
${ }^{2}$ DIRECTIVE (EU) 2016/97 OF THE EUROPEAN PARLIAMENT AND OF THE COUNCIL of 20 January 2016 on insurance distribution (recast)
${ }^{3}$ REGULATION (EU) No 1286/2014 OF THE EUROPEAN PARLIAMENT AND OF THE COUNCIL of 26 November 2014 on key information documents for packaged retail and insurance-based investment products (PRIIPs)

information documents for pact
"The following two regulations:

"The following two regulations: European Parliament and of he CoULATiON (EU) 20 COMMISSION DELEGATED REGULATION (EU) 2017/2358 of 21 September 2017 supplementing Directive (EU) 2016/97 of the European Parliament and of the Council with regard to product oversight and governance requirements for insurance undertakings and insurance distributors
Directive $2002 / 92 / \mathrm{EC}$ of the

ropean Parliament and of the Council of 9 December 2002 on insurance mediation 'Conditions are detailed in Article 16 of COMMISIION DELEGATED REGULATION (EU) 2017/2359 investment products requiring more extended information to be provided to the customer before sales.
${ }^{2} \mathrm{~A}$ Magyar Nemzeti Bank $8 / 2016$. (VI.30). számú ajánlása a befektetési egyśégekhez kötôtt (unit-linked) életbiztositásokkal kapcsolatos prudenciális ès fogyasztovededelmi elvek alkal mazásáról 10Notation to foreign readers: There's such a regulation in Hungary that oblige life insurers to publish the TKM ratio (Total Cost
Indicator - sum of costs and charges in percentage form) of saving life products sold. This TKM ratio is mostly similar to RiY

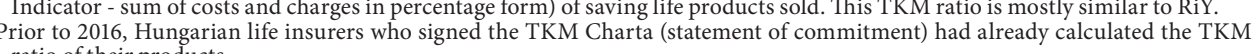

\section{IRODALOMJEGYZÉK}

DIRECTIVE (EU) 2016/97 OF THE EUROPEAN PARLIAMENT AND OF THE COUNCIL of 20 January 2016 on insurance distribution (recast) the European Parliament and of the Council with regard to information requirements and conduct of business rules applicable to the distribution of insurance-based investment products COMMISSION DELEGATED REGULATION (EU) 2017/2358 of 21 September 2017 supplementing Directive (EU) $2016 / 97$ of the
European Parliament and of the Council with regard to product oversight and governance requirements for insurance undertakings

and insurance distributors ors
2014. évi LXXXVIII. Törvény a biztositási tevékenységröl 